\title{
Deconstruction or Reconstruction: Reading Shelley's Prometheus Unbound
}

$\mathbf{M}^{\text {ore }}$ ore conspicuously than those of Wordsworth or Keats, Shelley's poems are accompanied by prefaces that place a hermeneutic frame around them, pleading with the reader for their sympathetic reception yet thereby recognizing that what they try to 'say' is subject to dissent. The writing of prefaces, however, is only a symptom of a more pervasive awareness that the imagination is not autonomous. The ways in which reading becomes the dialogical supplement of writing are a central concern of the two later poems we shall consider. But the problem of reading, though deferred, is present on the margins of more hermetically visionary poems as well. In this respect Alastor can provide us with a pre-text for raising problems that Shelley explicitly confronts in his later work. For its defense of 'poetry' is attempted through a hermeneutics of negativity that stops just short of consuming what it struggles to protect and that requires us to reconceive both the role of deconstruction in semiosis and the nature of reading.

Alastor is a highly reflexive poem that enacts simultaneously the processes of making and reading. In conflating these two activities, it nevertheless elides the deconstructive dialogue between them that Shelley must confront in Prometheus Unbound. The poem is in the first place about the writing of itself. As a poet himself, resuming his "longforgotten lyre" (1. $4^{2}, S P P$ ), the Narrator has the task of animating what reverts at the end to "An image, silent, cold, and motionless" (l. 661, $S P P)$. He must give substance to the Poet, who is otherwise an empty sign, threatening to deconstruct a romantic ideology of vision that becomes no more than an intent of consciousness. But this struggle against the counterspirit of language proves to be a troubled one, because the 
Narrator's attempt to make the Poet speak to us takes form not as the inspired song he originally plans (l. 19, $S P P)$, but as poetic narrative: in a form that keeps complicating the drive toward idealization by entangling it in a story of particular facts. Converting lyric into narrative, the text defers the identity of the Narrator with his own mood. For subjective narrative of the kind produced in Alastor is caught in a series of differences: in the difference of the Narrator from an alter ego with whom he cannot quite identify, and in this case in the internal differences of a story that must be told twice over and that is eventually abandoned rather than concluded. ${ }^{1}$ Moreover, as a text addressed to someone rather than simply "overheard," as Frye says of the lyric, ${ }^{2}$ such narrative is 'poetry' produced at the site of interpretive dissent. It is already aware that its readers might think otherwise, incipiently dialogized by this awareness.

But at the same time the Narrator's attempt to write the figure of the Poet is already a hermeneutic, not a mimetic or creative act; the Narrator does not commemorate someone he has known intimately, like Wordsworth remembering Lucy. Like the speaker of the conversation poems he tries to understand from the outside an experience he has not had but struggles to believe in. That he tells it twice testifies to his persistence in trying to get to the heart of the Poet's story. His attitude to a visionary ideology whose authority is felt only as an absence thus models for us the role of the reader who must overcome doubts that are created by the fact that we live in the twilight of the idols. It is therefore difficult to imagine the Poet except as a "twilight" phantasm (l. 40, SPP), and indeed to construct him except as a character without interiority, a mere sign of what he wants to be. Indeed, the hermeneutic modeled here is considerably more negative than that of Coleridge. Where Coleridge is able to invest the experience he would have us recover in another person, the Narrator does not clearly represent the Poet as having had a visionary experience. 'Vision' is disturbingly accompanied by fainting (ll. 188-91, $S P P)$. and if "meaning" once flashes on the Poet's "vacant mind" (l. 126 , $S P P)$, it is never represented in language. That the Poet is essentially a representation is marked in the preface, where his life is described as "allegorical" ( $S P P$, p. 69). As sign, he posits nothing except the desire to posit. For the preface negates the Poet as "self-centred" but then negates

${ }^{1}$ I discuss the doubling of the narration and the relationship between lyric and narrative in "The Web of Human Things: Narrative and Identity in Alastor," in Kim Blank, ed., The New Shelley: Later Twentieth-Century Views (New York: Macmillan, forthcoming). For a general discussion of lyric versus narrative modes see my essay "Romanticism and the Death of Lyric Consciousness," in Chaviva Hosek and Patricia Parker, eds., Lyric Poetry: Beyond New Criticism (Ithaca, N.Y.: Cornell University Press, 1985), pp. 194-207.

2Northrop Frye, Anatomy of Criticism: Four Essays (Princeton, N.J.: Princeton University Press, 1957), p. 249. 
the "meaner spirits" who do not follow his example, so as to signify through this double negation a desire for the visionary that is not embodied in the Poet himself (SPP, pp. 69-70).

What the Narrator attempts is, however, a hermeneutics of negativity that makes us aware both of a powerful resistance to deconstruction and of the crisis faced by such resistance. Crucial to his strategy is the estrangement of the Poet, whose journey through regions that are culturally and temporally distant draws our attention to a hermeneutic problem, while also putting the Poet in the space of the auratic. Scattered through the poem are references to the Orient that try to make the vacancy repeatedly alluded to in the poem into an occultation of meaning. Nature finally builds a "pyramid" over the Poet's moldering bones (l. 53, $S P P$ ), and while alive he is represented among obelisks and sphinxes (ll. $111-16, S P P$ ), lingering among "memorials / Of the world's youth" in places where "dead men / Hang their mute thoughts on the mute walls around" (ll. 119-22, SPP). These images function as signals to the reader which reverse what Geoffrey Hartman has presented as a 'westering' movement in romantic poetry ${ }^{3}$ and ask us to construct the sublime from within the hermeneutic. But it is not a question of deciphering that cipher which is the figure of the Poet, for the Oriental exists only as the negation of our own world, and thus as a dead world. More helpful than theories that associate hieroglyphs with a lost origin is Hegel's account of Egyptian art as the crystalization of the symbolic phase:

Egypt is the country of symbols, the country which sets itself the spiritual task of the self-deciphering of the spirit, without actually attaining to the decipherment. . . . But their works remain mysterious and dumb, mute and motionless, because here spirit itself has still not really found its own inner life and still cannot speak the clear and distinct language of spirit. $(A, I, 354)$

Hegel's description helps to explain why the visionary mode in Alastor is conceived only negatively, in terms of silence, absence, vacancy. For the visionary is still only a figure of itself. Crucial to the negativity of Egyptian art are the pyramids that take form as "a double architecture, one above ground" and obviously constructed only for the sake of the "inner meaning" it envelops, the other "subterranean" but consisting of an intricate network of labyrinths and hieroglyphs, one might say of further signs. These signs, moreover, construct a world that is dead. According to Hegel, Egypt turned from the phenomenal world to the inward, but conceived "as the negative of life, as death," such that "the

${ }^{3}$ The Fate of Reading and Other Essays (Chicago: University of Chicago Press, 1975), pp. 126-27. 
immortality of the soul" is still only conceptualized as the "preservation of corpses" ( $A, \mathrm{I}, 355)$. The 'reorientation' of Alastor therefore involves grasping the text as the sign of some inner meaning that is absent. It also involves seeing an otherwise nihilistic emphasis on death-on the Poet's moldering corpse-as an embalming of that which remains still (to be) born. Augmenting our sense of the visionary mode as lifeless is the fact that the Poet almost never speaks, spending his days among "speechless shapes" (1. 123, SPP). But muteness for Hegel is not the death of the sign, but rather the site of the text's delivery to and by the future. Egyptian art is summed up by the statues of Memnon, which "numb, stiff and lifeless, are set up facing the sun in order to await its ray to touch them and give them soul and sound." Unable to "draw animation from within" like the human voice, these statues require "light from without which alone liberates the note of the soul from them" $\left(A, \mathrm{I}, 35^{8}\right)$.

For the reader outside the text, however, it is difficult not to see the hermeneutics of negativity described here as a mystification. Denying itself the constructive force of prophecy, the poem's elegiac orientation toward the past constantly thwarts our attempts to posit something on the ground of the Poet's absence, by reinscribing them in the Narrator's failure to represent him. The phenomenological recuperation of death as a state of consciousness thus comes up against the materiality of death, against the sense that it is the obliteration of what survives only as a trace. Or to put it differently, the Poet's death still has the force not of transcendence but of a double negation: a negation both of the ordinary and of the visionary. Any attempt to make it into a transcendence is suspended by the way in which this text exchanges author and reader functions so that neither can be self-grounding. For the Narrator's attempt to give the Poet an identity emerges as a hermeneutic act, such that writing is already interpretation and not a reflection or expression of truth. But, on the other hand, the reading of identity emerges as figurative because the muteness of the Poet prevents it from being a reconstruction of something already said or thought. We have seen how such instability can become an occasion for reformulating the relationship between text and reader. Indeed, the double negation of the preface asks that we read beyond the poem and open it to historical reformulations of the dialectic between the visionary and the social. But the poem itself seems committed by its form as a quest (for truth) and by the hermeneutics of elegy to an essentialism that preempts heuristic reading. As elegy, Alastor stands at the opposite pole from The Triumph of Life, where it is not the living who must turn toward the dead but the past that must encounter the present. Michael Fried has described how painters in the age of Diderot found it necessary to include the beholder as witness to their truth, only to turn away from him as the site of their 
insertion into a world outside the hermetically sealed enclosure of the canvas. ${ }^{4}$ This tension between 'absorption' and 'theatricality' parallels the ambivalent attitude of traditional hermeneutics toward the reader: an ambivalence particularly evident in the fact that the elegy frames the role of the reader within the death of its subject. Like those paintings that invite us to watch them turning away from us, romantic elegy asks us to join in re-membering its subject, while sealing it against further reading by leaving us with the reproach of the Poet's death. For the dead elicit sympathy but also guilt, such that any understanding that is also critical becomes like a violation of the sacred.

To compare Prometheus Unbound and Alastor may seem unusual, but the later text is again concerned with the mediation of a visionary ideology. The problem of mediation is raised by the very mode of lyrical drama, which Shelley defines in the preface to Hellas as a difference between vision and history that signals the intentionality of the former:

The subject in its present state, is insusceptible of being treated otherwise than lyrically.... I have, therefore, contented myself with exhibiting a series of lyric pictures, and with having wrought upon the curtain of futurity which falls upon the unfinished scene such figures of indistinct and visionary delineation as suggest the final triumph of the Greek cause. (SPP, p. 408)

We can reformulate this by saying that the materiality of narrative and drama, of writing vision into the language of events, inevitably defers the re-visioning of history as the phenomenology of mind. Appealing to futurity, Shelley experiments with the idea of a prophetic hermeneutics that will read beyond the indistinctness of his play. But in transposing lyric into drama, he also submits vision to the theatricalization of which the romantics were so deeply suspicious. ${ }^{5}$ We can therefore expect that he will deal much more explicitly with the problematic relation of 'poetry' to its audience.

For much of its history, critics have emphasized how Prometheus Unbound fails as an act of representation. Such assessments, though insensitive to the ways the play encodes its own textuality, seem more accurate in describing its construction than the organicist readings that replaced them. From the nineteenth century onward, critics have accused the play of being "intangible," "vague and hollow," populated by characters who

\footnotetext{
${ }^{4}$ Absorption and Theatricality: Painting and Beholder in the Age of Diderot (Los Angeles: University of California Press, 1980), pp. 103-4.

${ }^{5}$ Ibid., p. 104 .
} 
are "spectral, of ten formless, sometimes only voices."6 Some of the gaps in its logic are thematic. The movement of history toward the far goal of time is seen in linear and eschatological terms, but the historical process is also imaged as a cyclic one in which the infirm hand of Eternity may allow Jove to return again. Other gaps are dramatic. Demogorgon, a volcanic and amoral power who sees the deep truth as imageless in the early part of the play, suddenly becomes Olympian and beneficent in a fourth act that lifts the veil and does image ultimate reality. Yet other gaps have to do with the semiotics of the play's characterization, which hovers uncertainly between the external and the internal. For instance, while Prometheus himself remains chained to the rock, two secondary figures carry out the task of ending the Jovian age. Asia, whose ethic of love is consistent with Prometheus' forgiveness of Jupiter, must be seen psychologically as a force within Prometheus, if the latter's change of heart is to be viewed as something active and not merely contemplative. But Demogorgon, whose violent overthrow of Jove represses rather than forgives him, is conceived allegorically as a power beyond Prometheus himself. Yet if Asia is internal to Prometheus, can we really dissociate Demogorgon from a Prometheus who is then caught in the paradox of using violence to achieve peace? It is hardly surprising, in view of such contradictions, that the triumphant fourth act seems an aria tacked on to a three-act drama, rather than an organic resolution.

Perhaps the most troubling lacuna in the play has to do with the unilateral nature of Prometheus' forgiveness of Jove, on which the entire action depends. If Promethean love is indeed to inaugurate a new age, then surely this love cannot remain a paradise for a sect. Yet it is only the Jove within Prometheus who is overcome by love. The actual Jove, in a scene reminiscent of Paradise Lost where Satan is hurled headlong only to rise again, is cast into the abyss: repressed rather than reintegrated. These local aporias are, moreover, reflected in the text's ambiguous genre. Prometheus Unbound is of ten described as a political allegory. As a political work it assumes the legislative, even the executive, authority of words. But as an allegory it concedes that the world it represents exists at a certain distance from actuality and must be rendered abstractly rather than realistically. Moreover, Shelley himself described Prometheus Unbound through another paradox when he subtitled it a lyrical drama. As drama, it claims an objectivity at odds with its of ten diaphanous language. A dramatic action is concretely, materially present before us. Drama is, moreover, a communal mode: because it communi-

${ }^{6}$ See L. J. Zillman, Shelley's Prometheus Unbound: A Variorum Edition (Seattle: University of Washington Press, 1959), pp. $4^{1-42,} 44$. 
cates to an audience, it assumes a shared ideology and an affective link between words and the world outside them. Yet Shelley's play is a lyrical drama, by definition impossible to stage in the theater of the world, and acknowledging for itself a merely private and subjective status. Interestingly, Shelley himself expected it to be read by no more than twenty people, perhaps as few as five. ${ }^{7}$

Faced with such disjunctures in the play, the response of modern critics has been to use an aesthetic version of the argument from design. $\mathrm{K}$. N. Cameron, for instance, raises the question of why Demogorgon is described as having existed from time immemorial and then is introduced in act III as the child of Jupiter and Thetis born to overthrow his father. Making Demogorgon the fatal child is necessary to show how tyranny breeds its own destruction. But an awkward by-product of this new parentage is that Demogorgon, previously an abstract force outside time, now becomes historically specified as a revolutionary power within the world of time, liable to be consumed by the future as he has consumed the past. Cameron's response is to argue that this ungrammaticality makes sense on a deeper level. Jove is mistaken when he identifies his fatal child with Demogorgon, and evidently Demogorgon himself, when he identifies himself as Jove's child (III.i.54, SPP), is speaking only metaphorically, although he is speaking literally when two lines earlier he identifies himself with Eternity. ${ }^{8}$ This argument, however, seems ingenious. If Shelley simply wanted to have Jove overthrown by his child, we must ask why he had to create confusion by identifying the child as Demogorgon when Hesiod and Aeschylus make no such identification. He wished, of course, to show the revolution as engendered within history. But he could have given the fatal child some other name, except that identifying it with Eternity is also necessary if the Promethean revolution is to have a transcendental guarantee and not to be a purely local event. Moreover, it is not simply Demogorgon's identity as the child of Jupiter but also his identity as "Eternity" which is in question. In act III he announces that he is Eternity (III.i.52, SPP); in act IV he refers to "Eternity, / Mother of many acts" (IV.565-66, SPP), as though Eternity is something other than himself, and as though he is not supreme but subject to some other force. Between Demogorgon the first cause who resides in the realm of res cogitans, and Demogorgon the effective cause operating in the sphere of res extensa or historical events,

${ }^{7}$ See W. E. Peck, Shelley: His Life and Work (1927; rpt. New York: Burt Franklin, 1969), II, 125; Shelley, The Complete Works, ed. Roger Ingpen and W. E. Peck (London: Ernest Benn, 1926-1930), X, 354 .

${ }^{8}$ K. N. Cameron, "The Political Symbolism of Prometheus Unbound," PMLA 58 (1943); rpt. in R. B. Woodings, ed., Shelley: Modern Judgments (London: Macmillan, 1968), pp. 121 24. 
the link is as unclear as the one Descartes constructs between his two spheres via the pineal gland. Or to put it differently, Shelley cannot make the transition from the sphere of thought to that of actuality, a problem not untypical of revolutionary thinkers, and also fundamental to the status of the play's revolutionary discourse. One could go on, but the point is a simple one. It is that one can construct exits from the interpretive labyrinth of the play if one tries. But any attempt to clarify the play's dramatic syntax simultaneously generates further ungrammaticalities. ${ }^{9}$

Described this way, the play invites scepticism. But Prometheus is a consciously metafictional text whose deconstruction is part of the dialogue on aesthetics set in motion by the Defence. It includes at least two scenes of understanding which reflect on the process by which a unified truth is constituted, communicated, and confirmed: the dialogue between Asia and Panthea at the beginning of act II and Asia's visit to the Cave of Demogorgon later in the act. The first of these comes immediately after act $I$, which reluctantly recognizes the discourse of hope as hypothetical. The two crucial episodes of act I-the encounter between the reformed Prometheus and the Phantasm of Jove, and the psychomachia that balances the Furies against the Spirits of hope-do not simply convey the play's optimistic propositions. They also reflect back on themselves and must be viewed semiotically as well as thematically. In Prometheus' revocation of his curse, voice is deliberately decentered. His words are split away from their original speaker and attributed to Jove, himself not a person but a phantasm, an empty schema like the subject in Lacanian psychoanalysis. The words do not seem to come from anywhere or from anyone: they do not belong and are therefore inappropriate. This curious device, which has an effect similar to that which Brecht describes as Verfremdung or alienation, suggests that the Jovian element in Prometheus is no longer a part of his thinking. But it is also used to remove from those words the ability to affect the real world that comes from their being centered in a speaking self. Deprived of the validating authority of the emotions that generated them, Prometheus' words become simply words, grounded in nothing outside themselves. But the decentering of the text of hate inevitably makes us aware that its successor, the text of love and forgiveness, is also an intent of consciousness. To put it differently, Prometheus uses the fact that he exists within

\footnotetext{
9I borrow the term 'ungrammaticality' from Michael Riffaterre, who uses it to indicate an element that disrupts the manifest grammar of a text and that thus threatens "the literary representation of reality or mimesis": Semiotics of Poetry (Bloomington: Indiana University Press, 1978), p. 2. Unlike Riffaterre, I do not believe that the ungrammaticality is part of "a deviant grammar or lexicon" that is eventually integrated into a unified system of signification.
} 
the prisonhouse of language precisely to argue that the semiotic manacles he has created by perceiving his relationship to Jove in a certain way are mind-forged. But in making the past into a text that he can rewrite, he semiotizes the future, making it, too, into a text that may lose its grounding in reality if it does not find readers with a similar emotional tropology. The result is a displacement of the play's subsequent action from the status of signified to signifier. This displacement will be accentuated throughout the play in the use of aesthetic rather than natural analogies to evoke the process of Promethean renewal. ${ }^{10}$

The summoning up of the phantasm can in fact be seen as mise-enabime of the larger play. Occurring entirely inside Prometheus' consciousness, it reduces the play's action to a play with images, disclosing the immateriality of what Shelley describes as writing "drawn from the operations of the human mind" (SPP, p. 133). Equally problematical is the remainder of the first act. The Furies are depicted as insubstantial phantasms from "the all-miscreative brain of Jove" (I.448, SPP). But the matching of the spirits against the furies suggests that they may be no different. Not only do the spirits have difficulty envisioning a world in which ruin is no longer love's shadow, the fact that their tenuous vision of a redeemed world takes the form of a dream acknowledges that imagination cannot give a foundation to what it posits except as an intent of consciousness.

It is against this background that we must see the dialogue between Asia and Panthea in which Shelley reflects on the rhetorical problem at the heart of the play: that of whether he can make his vision of a Promethean Age convincing, given the lacunae in it. Again, the vision takes the form of dreams, subliminally felt as Panthea sleeps in Ione's arms in the depths of the sea. The scene focuses on the difficulty she has in articulating her two dreams about the psychological resurrection of Prometheus and the future heralded for the rest of mankind by his transformation. Thus it raises the two problems central to the poetic process: that of expression, the finding of signs to signify the ineffable, and that of persuasion, the creation of an interpretive community that will give assent and solidity to an otherwise esoteric vision. It is the latter alone that can fulfil the imperatives of Shelley's form by translating lyric into dialogue and finally drama, visionary intention into communication and action. Panthea in this scene functions as the implied author, the hierophant of "an unapprehended inspiration, (SPP, p. 508), while Asia is the reader desired by the author and one who "produces" the meaning of the text by intuitively grasping his intention. Shelley's essential work, as distinct from his published text, is figured here in the form of the

${ }^{10}$ Cf. Prometheus Unbound, ll. 661-63; III.iii.16o-66; IV.153-58, 212-13, 236-40, SPP. 
dreams. The word 'text,' meaning something that is woven together, designates a collection of signs with grammatological but not pneumatological status. Its relationship to the term 'work' is, to borrow his own distinction, like that of a mosaic to a painting, a mosaic being a conglomerate of parts and a painting being a unified whole (SPP, $\mathrm{p}$. 504). Although Panthea's words (like Shelley's text) serve as conductors of the play's vision, this vision remains scattered as long as Asia attempts to ground it in the words themselves, which are transitory and fragmentary, imaged in terms of winds and air (II.i.37, 109, SPP). In short, at the beginning of the scene we are able to scan the textual mosaic but unable to grasp the work.

The roles of Panthea and Asia correspond almost exactly to those Schelling assigns to the two sides of the self at the beginning of The Ages of the World. Schelling conceives of understanding as a dialogical process, but one that culminates in identity rather than difference, the difference being due to the process of articulation and the ultimate identity of questioner and respondent being also a finding of identity. Understanding is first of all a process of recollection and recognition by which we reawaken the "archetype of things [that] slumbers in the soul like an obscured and forgotten, even if not completely obliterated, image" ( $A W$, p. 85). But this we accomplish through dialogue, which enables us to make conscious what we sense only obscurely, by learning it from another who turns out to be an objectification of ourselves. In the phenomenology of understanding, which can serve as a model for the reading process, there are two participants: "an asking one and an answering one, an ignorant one which, however, seeks knowledge, and a knowing one which, however, does not know its knowledge." The higher, intuitive self, in Schelling's words, "is mute and needs a mediating organ in order to attain expression" ( $A W$, p. 89). Similarly, in Prometheus Unbound Panthea, though in possession of what Shelley calls "the uncommunicated lightning" of the play's vision, (SPP, p. 134), is ignorant of what she knows and needs Asia to produce her vision. That the vision is inarticulate until it is read is a significant point, and one whose deconstructive consequences will emerge in the visit to Demogorgon. But for the present it is enough to say that the reader here is given the responsibility of recovering and in some sense co-creating a vision that otherwise would "not speak to us, but remain dead" $(A W$, p. 88).

Communication proceeds only when the internalizing of knowledge described by the German word for recollection, Erinnerung, occurs through an identification of author and reader. Suddenly, Asia discovers the right method of reading by gazing into Panthea's eyes and there reading Prometheus' "written soul" through a paradoxically "wordless converse" (II.i.1 10, 52, SPP). The logocentric concept of the "written 
soul" resolves the paradox of traditional hermeneutics: the paradox that in order to preserve vision one must fix it in writing, but that writing is always external and supplementary to what it transmits. ${ }^{11}$ The process of moving beyond the linguistic sign to the language of the eyes suggests how the reader, too, can break the hermeneutic circle by moving beyond a semiological reading that decenters vision to a psychological reading that allows us unmediated access to the inner core of the work. The breaking of this circle serves as a catalyst for the communication of Panthea's second dream, which turns out to have been Asia's also. Thus we can see in this scene the outlines of a Shelleyan hermeneutic designed to reverse the deconstructive potential within a text that fails to confirm itself by meeting the classical criteria for unity. The published text, composed of disjunctive elements that can be brought together only by imaginative leaps, is seen as a product of the semiotic fracture described in the Defence, which occurs when inspiration is signified through composition $(S P P$, p. 504). But the scene dramatizes the imaginative project as interpersonal communication rather than simple linguistic intention involving a dyadic relationship between the sign and the thing or concept signified. In other words, it presents reading as a psychological and not just a semiological process. Asia responds to Panthea's dream, not on the level of its fractured signifiers, but through a process of what Dilthey calls "reconstruction" (Nachbildung). By translating a language initially "given us only from the outside" in terms of "our own sense of life," Dilthey argues, we center the isolated signs "given to our senses" in a "coherence experienced from within." 12 This coherence, though subjective, is also shared between author and reader. Panthea's attempt to voice her dream is an invitation to Asia as implied reader to re-cognize the dream she herself has had. As such, the dialogue between the two sisters serves as a model for the dialogue intended to occur between author and reader. Critics have of ten complained that the fourth act is like a castle in the air. But the insubstantiality of the play's action is not the point, because the action cannot become real until we as readers recognize it as the dream we have had. The fourth act, in which Shelley stages an objectively unverifiable outcome in the theater of his own mind, invites us to stage Shelley's vision in the theater of our minds and thus bridge the gulf between intention and actuality conceded in the notion of lyrical drama.

As an intratextual allegory of the transmission of text to reader, this scene is of course stage managed. By imaging the author and implied

${ }^{11}$ Wilhelm Dilthey, "The Rise of Hermeneutics," trans. Fredric Jameson, New Literary History 3 (1971-72): 232-33.

12 Ibid., p. 231. 
reader as sisters, Shelley assumes a reading based on sympathy, a dialogue that is no dialogue because the Other is the emotional twin of the self. It is this same assumption of psychic affinity which allows him in The Defence to construct a hermeneutics of understanding in which reading is the redemption of a fragmentary text through the animation of archetypes that point to the intention in which the text has its genesis $(S P P, \mathrm{p}$. 505). But it is necessary to distinguish between the implied and the explicit readers: using the term "explicit reader" as $\mathrm{H}$. $\mathrm{R}$. Jauss uses it to distinguish the actual historically differentiated reader from Iser's idealized "implied reader" whose role is prescribed within the text. ${ }^{13}$ Though this reader by definition is not figured in the play, the reader's presence as a potentially negating force is something of which Shelley seems aware even in the dialogue between Asia and Panthea, but more strongly in the visit to the Cave of Demogorgon.

One of the changes that Shelley made in the draft manuscript of the play casts considerable light on the way he problematizes the hermeneutic journey undertaken in the second act. When Asia asks her sister to raise her eyes so that she can read Prometheus' soul in them, the draft shows Asia experiencing an ecstatic communion with the burning image of Prometheus in Panthea's eyes: "It is his spirit in their orbs." 14 This passage is deleted in the published version, which goes straight on to Panthea's troubling question: "what canst thou see / But thine own fairest shadow imaged there?" (II.i.112-13, SPP). Panthea here points out that her eyes may not be a window into some ultimate reality but a mirror in which Asia sees the projected text of her own desire. Read in the light of the deleted passage, the sceptical potential of this question is neutralized, and Panthea's question can be taken positively as meaning that the soul of the work, the vision of Prometheus, is also a reflection of Asia's epipsychic essence, her fairest shadow. It thus guarantees the culmination of the interpretive dialogue between author and reader in a fusion of horizons, accomplished literally through an act of vision. Read without the deleted passage, the question becomes more sceptical and suggests that the supposed essence of the work is a projection by the interpreter of her own self, which is itself a construction, an 'image' momentarily constituted in the kaleidoscopic process of communication rather than preceding it. We will return later on to this point about the semiotics of identity: that of author, reader, and character. Suffice it to say that Asia's response to Panthea's question about the nature of the text read in the eyes is contradictory: she at first confirms the hermeneu-

13"Theses on the Transition from the Aesthetics of Literary Works to a Theory of Aesthetic Experience," in Mario J. Valdes and Owen J. Miller, eds., Interpretation of Narrative (Toronto: University of Toronto Press, 1978), p. 142.

${ }^{14}$ See Zillman, Shelley's Prometheus Unbound, p. 187. 
tic myth of transparent communication by paralleling Panthea's eyes to "the deep blue, boundless Heaven" (II.i.1 14, SPP). But then she suggests that what she reads there is a labyrinth of tropes: "dark, far, measureless, - / Orb within orb, and line through line inwoven.- (II.i.1 16-17, SPP), an image for visionary communication that is repeated in the "life of life" lyric, where Asia's eyes are paralleled to mazes (II.v.53, SPP). It is true that Asia here goes on to announce that the hermeneutic circle has been broken when she declares: "The dream is told" (II.i.1 26, SPP). But the seeds of the later scene have already been sown. We are aware that the notion of a language that is grounded in something beyond language may be itself a linguistic construct and therefore subject to doubt and dismantling.

Even more unsettling for a hermeneutic reading is the second interpretive interlude, Asia's dialogue with Demogorgon. Immediately after their conversation the sisters follow the echoes of voices into a forest that presumably leads into the depths of consciousness and toward the origin of things. This journey is the narrative equivalent of the process that Husserl describes as reduction or epoché, by which one seeks to reach the transcendental subjectivity, in this case, of the author. The shift from dialogue to lyric at the end of the first scene and in the dialogue of the Fauns signals a bracketing of the external world. The voices of the speakers are no longer dramatically differentiated, and their lyrical oneness is an attempt at what Schelling describes as the annulling of "all duality in one's self, so that we would be, as it were, only inwardly, and live altogether in the supramundane, discerning everything immediately" ( $A W$, p. 88$)$. But the sisters' journey ends in the Cave of Demogorgon, where the philosophical foundations of traditional hermeneutics are eroded, as Shelley once again brings into the foreground the problems of communication, interpretation, and reading. Asia's conversant is no longer her sister but Demogorgon, a being who is sexually and ontologically other than her. The scene reflects on the opacities of communication, and though the explicit reader is not figured in the text, the reader's potentially negating presence emerges from the gaps and silences where the dialogue within the text fails to become a meeting of minds and thus reflects back on reading as dialogue. But the scene is only obliquely about the relationship of the implied to the explicit reader, and in fact is about something more radical which subtends this relationship: the relationship of the reader to the work itself. Ostensibly, the scene repeats the earlier one and ends with Asia as implied reader "producing" the meaning of Shelley's work when she acts on her perceptions and perceives in a positive light what is actually a very ambiguous event: the appearance of the two chariots that herald some momentous historical change. Ostensibly, then, it is the active mirror image of its 
contemplative counterpart: in the first scene Asia understands the work and articulates its vision; in the second scene she translates it from the sphere of expression to the sphere of events. But in fact the scene renders highly problematical the reading for which Asia serves as missionary, by dismantling our earlier security as to what the work says, and what the animating intention behind it is.

Crucial to this second scene is the figure of Demogorgon, a character who again seems an empty schema rather than a tangible personality. If Panthea was the means by which the reader made contact with the essence of the work and the spirit of its author, then Demogorgon is her antithesis: the means by which we recognize that the inner core of the work is absent, its voice "lacking," its cryptic and contradictory text all that there is. 'His' eyes cannot be read. 'His' curious lack of personality denies the possibility of communication except on a grammatological level, and indeed the inconclusive dialogue between Asia and Demogorgon of ten revolves around the signifier. It is halted by grammatical problems such as the specification of an antecedent to a pronoun, as in Asia's attempt to find out what is meant by "He reigns" (II.iv.28, 31, $32, S P P)$, and it is held up by the need to identify an abstraction that stands in place of someone whose identity we are never told, such as the destiny in the chariot (II.iv.146, SPP) or "God" (II.iv.112, SPP). Asia is once again the implied reader who believes in the sacred necessity of hope: the reader we might suppose to be desired by Shelley or by a part of him. As a dramatic character, she seeks a meeting with her creator or his intermediary that will allow her to understand the destiny of the created world. As implied reader, she seeks a fusion of horizons with the author that will enable her to grasp the essence of the work and then act on her intuition. But she succeeds in neither aim, for Demogorgon, apparently the originating or intending force behind the play's events, proves ungraspable. Consequently, what in the earlier scene was the "soul" of the work, the vision of hope discovered behind its flawed form and language, now becomes itself a linguistic construct. Meanwhile, the inner core of the work, which Asia was once able to read in Panthea's eyes, has disappeared, to be replaced by a vacancy. The scene therefore complicates severely a traditionally hermeneutic reading that allows the unity of the work to be potential rather than actual. The reconstruction of the original work encouraged in the dialogue with Panthea is presented as the reconstruction of a unity that may not be there, a passionately optimistic attempt to center something that is decentered and unfocused, having, like Demogorgon itself, neither "form-nor outline" (II.iv.6, SPP).

Crucial to the philosophic dismantling of hermeneutic reading is the rigorously antiphenomenological character of this episode. For the scene 
probes not only the authority possessed by individual acts and speech acts, but also the semiotics of the self in which action and language have their origin. Traditional hermeneutics assumes the existence of a transcendental ego, an essential core within us which gives value to our words and which is guaranteed by its link to a similar spirit on the level of the macrocosm. It is this ego that we had seemed to grasp in the dialogue between Panthea and Asia, whose shared discovery of identity enabled them also to grasp the Promethean spirit of the age. The figure of Demogorgon, however, deconstructs any notion of history as an organic manifestation of a spirit, a developing SUM or I AM. It casts in doubt the phenomenological notion of a Geist or world-historical spirit elaborated by Hegel and also assumed in such catch phrases as 'the spirit of the age.' Moreover, what this scene does on the level of the world-historical spirit a much earlier passage, which is explicitly linked to this scene by its introduction of Demogorgon, does on the level of the individual self. Close to the beginning of the play, in Earth's enigmatic description of how the Magus Zoroaster met his own image in the garden, Shelley already raises the question of what there is behind the possibly kaleidoscopic formation we call the individual. Ostensibly, the question is raised to dismantle the credibility of Jupiter by phantomizing him. But the implications of Earth's speech resonate through the rest of the play and unsettle our reaction to other characters and hence the authority of what they say and do. We are told by Earth that behind the flesh-and-blood forms of those who "think and live" is an appearance, not a reality: that the essential self is variously an image, a phantom, a "vacant" shade (I.198, 216 , SPP).

For know, there are two worlds of life and death:

One that which thou beholdest, but the other

Is underneath the grave, where do inhabit

The shadows of all forms that think and live

There thou art, and dost hang, a writhing shade ... all the Gods

Are there, and all the Powers of nameless worlds, Vast, sceptred phantoms;

$$
\text { (I.195-206, SPP) }
$$

Moreover, as Shelley suggests in a canceled line, the encounter between the self and its other dooms us henceforth to interweave the two worlds of life and death, the ego and its deconstructed image. ${ }^{15}$ Thus, it is not

${ }^{15}$ See ibid., p. 143. The canceled line following "For know there are two worlds of life and death" is "Which thou henceforth art doomed to interweave." 
only Jove who becomes an echo within this ghost sonata, but Prometheus also, Demogorgon, and indeed everyone who thinks and lives. In Asia's visit to the cave, for instance, the thinking and living Demogorgon who will later overthrow Jove is dismantled before we meet him by our encounter with his vacant image, an encounter that exposes the later, active Demogorgon as a linguistic constitution. Although Prometheus in this play is not similarly dismantled by his shade, he is perplexingly absent from the drama he initiates. With the exception of one scene, act III, scene iii, he speaks only one line after act I (III.iv.97, SPP). Critics have sometimes rationalized the disappearance of the play's characterological center by seeing various secondary figures as projected parts of Prometheus, such that he is reassembled, like Albion, from his parts. ${ }^{16}$ But this only makes us question whether what we call Prometheus is a holistic entity, or a conglomeration of selves. When he and Asia retreat to the cave at the end of act III, we must ask, is this the cave that like the hermeneutic circle conceals a potential totality to be brought to light by a sympathetic reader? Or is it, like the Cave of Demogorgon, the site of a return behind what Lacan calls the mirror-stage, to a space where we uncover the original self, a vacant sign as yet untenanted by author or reader?

Asia, indeed, does tenant the space vacated in this episode. The scene ends with Asia acting out her reading by ascending in the chariot of hope, following her own statement that in the absence of any ultimate meaning, one may make one's heart the oracle of its own truth. But this time we must consider more closely the status of the discourse of hope that she offers us as the hermeneutic matrix of the play. The long dialogue between Asia and Demogorgon begins with a theogony in which she places Prometheus' transformation as a moment in the phenomenology of the world-historical mind, thus also accounting for the Jovian age as a fortunate fall. It ends with her decision to see the arrival of the two chariots positively, which prepares the way for her reunion with Prometheus, and metaphorically for the union of the revolutionary mind with the material world. Thus, the scene might seem to encapsulate and reveal the entire action, the arche and telos, of the otherwise obscure Promethean drama. But if Asia starts from the assumption we have already encountered in Schelling, that the spirit of the work is a "voice unspoken" (II.i.191, SPP) that emerges in dialogue, the scene disturbingly challenges the hermeneutic conception of understanding. For what it offers us is a dialogue that is Lacanian in structure, a dia-

\footnotetext{
${ }^{16}$ See for instance Frederick A. Pottle, "The Role of Asia in the Dramatic Action of Shelley's Prometheus Unbound," in G. M. Ridenour, ed., Shelley: A Collection of Critical Essays (Englewood Cliffs, N.J.: Prentice-Hall, 1965), pp. 133-43.
} 
logue that does not so much reveal the identity of the text as bring to light its difference from itself. Asia's redemptive theogony, as Stuart Curran has pointed out, is radically different from the cosmic history provided earlier by Earth, who suggests that there "never was a golden age, but only the continuous tyranny of Jupiter." 17 Though it is told in the past tense, Asia's account is no more than an interpretation. Crucial to its tenuous status is its dialogical setting, which in the relative silence of Demogorgon registers the possibility of another side to what is being said. That dialogue can function to accentuate our sense of language as difference was pointed out a long time ago by Harold Pinter, who suggests that "the speech we hear is an indication of that we don't hear. It is a necessary avoidance . . . which keeps the other in its place." 18 Indeed, Asia cannot quite avoid the other side of what she says, for the very length of her speech gives her space in which to complicate the idea of the Jovian age as a mere interregnum between the Saturnian and Promethean ages. It seems that Prometheus created Jupiter by giving him "wisdom, which is strength" (II.iv.44, SPP), even though Asia also claims that "Jove now reigned;" as though he is an autonomous entity (II.iv.49, $S P P)$. The uncertainty about whether Jove is an external oppressor or a figure for some self-destructive potential within the human race leaves us unclear whether the "speech" and "Science" that Prometheus gives humankind in a second attempt at organized innocence (II.iv.71-75, $S P P$ ) will not recreate 'Jove.' And indeed that doubt is registered in Asia's description of the "legioned hopes" that Prometheus awakens as narcotics that "hide with thin and rainbow wings / The shape of Death" (II.iv.59-63, $S P P$ ).

As significant as the insecurity of Asia's theogony is the tenuous way in which the sisters construct a link between signifier and signified in the interpretation of the two chariots. For this scene, after all, initiates the resolution of the plot. Carlos Baker speaks for Asia and for a long critical tradition when he sees the chariots, one dark and one light, as intended for Demogorgon and Asia, respectively. ${ }^{19}$ By associating Asia with the light chariot, and by making the force within the dark chariot serve the purposes of good, he sidesteps the possibility that the dark chariot may herald a second coming in which the center no longer holds. He makes destruction a prelude, rather than a Manichaean alternative to, construction. Yet the text is by no means so clear. Asia at first assumes that the dark chariot has come for her (II.iv.145, SPP), a possibility that the

${ }^{17}$ Shelley's Annus Mirabilis (San Marino, Calif.: Huntington Library, 1975), p. 4o.

18"Between the Lines," The Sunday Times, 4 March 1962, p. 25.

19Shelley's Major Poetry: The Fabric of a Vision (Princeton, N.J.: Princeton University Press, 1948), p. 107; cf. also K. N. Cameron, "Political Symbolism of Prometheus Unbound," pp. $119-20$. 
spirit never actually denies, as he announces ominously that the reality of what he is, is worse than it appears: "I am the shadow of a destiny / More dread than is mine aspect-“ (II.iv.146-47, SPP). Moreover, it is not certain whether "Heaven's kingless throne" (II.iv.149, SPP), which the dark charioteer threatens to demolish, refers to Jove's throne or to the authority of some power higher than Jove, whose overthrow might lead to total chaos. Although the spirit in the light chariot does announce that it has come to bear Asia to Prometheus (II.iv. 168, SPP), the spirits, as we know from a canceled passage at the end of the act, may well be voices from a heart that is its own oracle. Again, the positive construction put on the scene's ending is no more than an interpretation, supplied, significantly, by Panthea and eagerly taken up by Asia. And again the silence of Demogorgon makes us aware of another side to this interpretation. Panthea, we recall, was earlier the author who functioned as a medium for "the gigantic shadows which futurity casts upon the present." But the author, to quote Roland Barthes, is now a "guest" in his own text, "inscribed . . . like one of his characters, figured in the carpet."20

The deconstructive reading encouraged by Asia's visit to the Cave of Demogorgon would see the play's hiatuses as dismantling its attempt at a transvaluation of values through a logocentric act of mythmaking. For the authority of mythmaking is eroded by the contrivances of which it makes use: by the disjunctive structure and characterization. But the reading urged earlier might see the very disjunctiveness of the text as something that antithetically stimulates the reader to break the hermeneutic circle and grasp the synthetic totality of the work across its negativity. It may seem that the play consumes the hermeneutic reading it offers. Or to put it differently, it may seem that the scene in Demogorgon's cave resists any attempt to reduce it to a concessive clause in the play's dramatic syntax. Indeed, my argument has been that hermeneutics contains the seed of its own deconstruction, because making the reader a mediating element allows for an explicit as well as for an implied reader, and so renders problematical any sentimental reconstitution of text as work. But the presence of the reader similarly complicates a deconstructive interpretation, because the explicit reader may, after all, follow a range of reconstructive options from sympathetic understanding to demythologization.

The plethora of choices available to us is nowhere more evident than in the play's method of characterization as it guides us, again equivocally, to seek or resist a phenomenological understanding. It is helpful here to distinguish between allegorical and psychological or symbolic character-

20Image, Music, Text, trans. Stephen Heath (New York: Hill and Wang, 1977), p. 161. 
ization, using the distinction between symbol and allegory as de Man uses it with reference to rhetorical figures. ${ }^{21}$ Shelley's method of characterization, for the most part, is allegorical. Jove, the Furies, the various spirits, and Earth, are conventionally allegorical characters. Prometheus and Demogorgon are more complex. They have the abstractness, the hollowing out of "individuality," that Hegel sees as natural to allegorical characters ( $A, \mathrm{II}, 1177)$, and the concomitant emphasis on character as actant rather than personality, signifier rather than signified. But if their characterization manifests the split between tenor and vehicle proper to allegory as a figure, the tenor is less clearly specified than in the case of the other characters. Still, they, too, are products of an allegorical characterization that decenters personality, by splitting the discourse in which the subject manifests itself from the originating subjectivity behind the words, and giving us only the former. Allegorical characterization seems the logical extension of the semiotics of selfhood that emerges from the play's two encounters between the magian ego and its empty origin. But Asia and Panthea, on the other hand, are somewhat different: personalities rather than signifiers. Shelley's characterization is nowhere realistic, but these two figures, who are not dramatically fissured in the manner of Prometheus and Demogorgon, are drawn symbolically rather than allegorically. There is no split between discourse and self, and the words of the sisters therefore provide us with immediate access to the inner core of their psyches. The allegorical subject is a schema that we know through a relatively conventionalized discourse and not in its interiority. This method of characterization, which makes the various characters into constructs rather than persons, cuts against the psychological identification between the reader and the central voice(s) in the text crucial to hermeneutic understanding. Allegorical characters can only be read grammatologically, though in a framework that may be either structuralist or poststructuralist. But psychological characters, whether realistic or symbolic, demand a phenomenological reading. Since it is partly through its characters that one grasps the identity of a dramatic text, the play's ambiguous method of characterization leaves its identity in doubt.

This is not to say that a hermeneutic reading offers us the key to the play. The text itself clearly undermines the epistemological authority of such a reading, though it supports its ethical authority. But the reinscription of the hermeneutic as desire displaces us from any schematic use of deconstruction. Indeed, one might argue that a third approach is

${ }^{21}$ Paul de Man, "The Rhetoric of Temporality," Blindness and Insight: Essays in the Rhetoric of Contemporary Criticism, rev. ed. (Minneapolis: University of Minnesota Press, 1983), pp. $187-208$. 
suggested in Shelley's representation of the text as drama, as performance: a designation with profoundly antimetaphysical consequences. With Asia's decision to interpret the arrival of the chariot positively, the play seems to move to an optimistic conclusion. Indeed, Harold Bloom complains that in "Act IV the imagination of Shelley breaks away from the poet's apparent intention, and visualizes a world in which the veil of phenomenal reality has been rent." 22 More precisely, it is after act II, scene iv, rather than after act III that the play makes its great imaginative leap, electing quite consciously to produce the meaning of the play according to one particular version. Yet if we are to understand the status of the play's discourse beginning with Asia's ascent in the chariot, we must understand its relationship to the earlier part of the play. The second or active half of the play stands in relation to the first reflective or reflexive part rather as a dramatic performance stands in relation to the script that elicits it. ${ }^{23}$ The relationship between script and performance is not strictly symmetrical, because a performance is a production of the script, not a reproduction related to the script as a photograph to its negative (as Asia might like us to believe on her emergence from the Cave of Demogorgon). Script and performance exist in different spaces, the former being intentional and complex, the latter being a concrete actualization, which succeeds in being such only by a deliberate act of simplification: by repressing the traces of alternative performances that exist in the intentional space of script. What this means, given that the individual production of a play is personally and historically variable, is that Shelley's Prometheus as script is open to the deconstructive production that as performance it chooses to exclude. Or to put it differently, his staging of the Promethean myth in the theater of his mind has, as performance, the status of a concrete possibility: it is more than a merely abstract potentiality, but less than a reality. Shelley himself suggests in the preface that he is aware of his play as a performance. It is in the nature of drama, he argues, to use a certain "arbitrary discretion" in its reworking of inherited subject matter, to produce rather than reproduce an action (SPP, p. 132). Moreover, he concedes that his production of the myth is historically limited, being an effect of culturally conditioned tropes of understanding that operate through the individual: "Poets, not otherwise than philosophers, painters, sculptors and musicians, are in one sense the creators and in another the creations of their

22The Ringers in the Tower: Studies in Romantic Tradition (Chicago: University of Chicago Press, 1971 ), p. 96.

${ }^{23}$ For a discussion of the relationship between script and performance see Keir Elam, The Semiotics of Theatre and Drama (London: Methuen, 1980), pp. 208-9; see also Terry Eagleton, Criticism and Ideology: A Study in Marxist Literary Theory (London: Verso Editions, 1978), pp. 64-66. 
age" (SPP, p. 135). That the Shelleyan version is formed by the spirit of the age (a more romantic term for what we now refer to as "discursive formations") is the source of its momentary authority and also of its vulnerability. But the fact that the gospel according to Asia is performance and not metalanguage has another side to it. For it means that any interpretation of the play is also not metalanguage but performance: or as Josué Harari puts it: "any theory of the text is itself text."24

That the plot as a performance of the myth cannot be reified into an imitation of an action is a point that can be further clarified if we borrow the distinction between story and discourse made, among others, by Seymour Chatman. ${ }^{25}$ The story comprises the actual events of the narrative, while the term 'discourse' refers to a telling and thus an interpretation of the events. But the discourse of this play is ungrounded in a story. For the story of who invested Jupiter with power and of what the limits and extent of that power are is never clarified, because the various cosmogonic fictions provided only serve to complicate the matter further. Indeed, the story of Prometheus' forgiveness of Jove, the most pivotal event in the play, is also unclear, for all we really know is how Prometheus tells the story of his attitude to Jove from l. 59 onward, but not what actually happens within his psyche. For instance, only a few minutes before he announces that the quality of mercy is not strained, Prometheus vengefully pictures Jove being forced to kiss his bloody feet (I.49-52, SPP). One may argue that this is before the crucial recantation, though the transformation is too instantaneous to be wholly persuasive. But several lines after Prometheus' spiritual transformation, in his confrontation with the Furies, he appears still to feel the darker emotions of which we thought him purged and describes his mastery over these emotions by disturbingly paralleling it to the repressiveness of Jove: "Yet am I king over myself, and rule / The torturing and conflicting throngs within / As Jove rules you when Hell grows mutinous" (I.492-94, SPP). Thus we do not know whether line 59 states an intention or an actuality, and whether the optative mode ("the Curse / Once breathed on thee I would recall") is used because Prometheus has not yet met the phantasm of Jupiter or because he has not yet become fully capable of forgiveness. In other words, we do not know what happens at line 59, and know only how Shelley later stages the meaning of the play. The displacement of the action from story to discourse, from signified to

\footnotetext{
${ }^{24}$ Josué V. Harari, "Critical Factions/Critical Fictions," in Textual Strategies (Ithaca, N.Y.: Cornell University Press, 1979), p. 4 o.

${ }^{25}$ Story and Discourse: Narrative Structure in Fiction and Film (Ithaca, N.Y.: Cornell University Press, 1978), pp. 1, 19-22. For a critique of the Platonic dualism implicit in Chatman's distinction see Barbara Herrnstein Smith, "Afterthoughts on Narrative," in W. J. T. Mitchell, ed., On Narrative (Chicago: University of Chicago Press, 1980), pp. 209-32.
} 
signifier, is crucial to Shelley's emergent recognition that if the text of desire is to be saved, it can be saved only as performance and not as mimesis.

One indication of Shelley's willingness to untie the text he actually published is the curious organization of the manuscript in the Bodleian library, possibly one on which he worked both before and after publication. ${ }^{26}$ It begins with act IV and proceeds to alternate act I on the lefthand side of the page with the remainder of act IV on the right-hand side. The manuscript continues up to the middle of II.ii, then alternates part of the third scene on the left side with the remainder of the second scene on the right, and finally places the remainder of the third scene (the song of the Spirits) on the left-hand side alongside the crucial dialogue in the Cave of Demogorgon (II.iv). ${ }^{27}$ Textual scholars have explained away the state of the manuscript by suggesting that it is an intermediate draft in which Shelley transcribed the first three acts and then inserted the fourth act, known to be an afterthought, "wherever there happened to be a vacancy." 28 Yet the mechanical explanation does not entirely clarify why he left several pages at the beginning of the notebook blank, if he was not toying with the idea of putting something there. Still less does it explain why the unweaving of the play's linear

26Zillman, Shelley's Prometheus Unbound, p. 12.

27The Bodleian manuscript consists of three notebooks. MS E 1 begins with act IV and proceeds for 427 lines, slightly beyond Earth's ode on humanity as "one harmonious soul of many a soul" to some lines spoken by the Moon. At this point Shelley commences act I on the left-hand pages and continues to insert the remainder of act IV on the right-hand side. This notebook ends in the middle of the scene involving the Furies. MS E2, at least equally confusing, begins with the remainder of act I on the left-hand side. Several pages on the right side are left blank, and it is not until he reaches the middle of act II, scene ii, that Shelley again returns to his dizzying practice of dividing the play between the two sides of the notebook. Having placed all of the dialogue between Asia and Panthea and part of the next scene (II.ii.1-63: the semichorus of Spirits) on the left side, Shelley suddenly shifts the remainder of II.ii to the right-hand side. Thus the first part of II.iii, Asia's conversation with Panthea as they approach the volcano, is placed on the left side, beside the remainder of II.ii (the dialogue between the Fauns: $11.64 \mathrm{ff}$.). The second half of scene ii does not occupy as much space as the first half of scene iii, and Shelley therefore leaves one of the right-hand pages blank as he continues scene iii up to the end of Panthea's and Asia's conversation (II.iii. 53). The remainder of scene iii is now shifted from the left to the right-hand side. Thus the crucial interview between Asia and Demogorgon (II.iv) now occupies the left side, while the remainder of scene iii (the song of the Spirits: $11.54 \mathrm{ff}$.) is juxtaposed opposite it. MS $\mathrm{E}_{2}$ ends in the middle of II.iv. MS $\mathrm{E}_{3}$, far simpler in its disposition of the play, begins at II.iv. 124 and continues straightforwardly to the end of act III, sometimes but not always leaving the right-hand pages blank for corrections.

${ }^{28}$ C. D. Locock, An Examination of the Shelley Manuscripts in the Bodleian Library (Oxford: Clarendon, 1903), pp. 28-29. Zillman also points out that the transcription of act IV begins before that of act I. But his account of the remaining acts makes them sound simpler than they are: "This act (I) was completed on page $2 \mathrm{O}^{\mathrm{v}}$, with Act II following on $21^{\mathrm{v}}$ and continuing to the end of the book (page $43^{\mathrm{v}}$, line II.iv.74). Again Shelley continued directly into the next notebook (E.3), with the next line of Act II starting on page $1^{\mathrm{v}}$ and ending on $10^{\mathrm{v} "}$ (p. 22). 
succession is continued through the disarrangement of the second act. The redeployment of the parts of act I, moreover, is not just eccentric. The second and third scenes are split at logical points, and from the middle of the second scene onward the effect is antiphonal. Lyrical scenes are divided from and juxtaposed with dramatic ones. The lyrical segments are separated and transposed to the right-hand side, as if to stage a confrontation between the imaginary world projected by desire and the greater complexities of the linguistic order.

The manuscript is therefore quite different from the published text. For the linear action of the latter may seem to distinguish it from the 'open' texts described by Umberto Eco, which "the author seems to hand ... on to the performer more or less like the components of a construction kit."29 Indeed, it would be wrong to say that Shelley's text is ever completely open, that he is unconcerned about its "eventual deployment," 30 and it would be more accurate to say that he places a model for the text's deployment within a structure that exposes it as problematic. Nevertheless, the mobile text that emerges from the manuscript dissolves space and time, juxtaposing different temporal planes and placing the cancellation of the Hours alongside the period of Prometheus' enchainment. One is reminded of Shelley's statement that pronouns and tenses are grammatical intrusions ( $S P P$, p. 483 ), and of the many romantic projects for dissolving boundaries, whether they be between different spatiotemporal orders or between different perceptual modes. Indeed, as in Blake's later prophecies, the impulse behind this aesthetic and temporal syncretism is partly to redeem time by making all time eternally present. But one may also be reminded of Nietzsche's statement that to abolish grammar might finally be to get rid of God. ${ }^{31}$ For the cubist disassembling of the text radically upsets our sense of a fixed perspective on events. The interpretive results of placing the last act at the beginning, for instance, are by no means easy to discern. It may occupy a prefatory position and inform us how to read the play. Or it may project a lyrical vision, only to parody the dangers of moving too quickly to the end of the play by exposing the perilous underpinning of this vision in the preceding three acts. That parts of the play can be placed in different spatial positions emphasizes that every event must be viewed in more than one way. For instance, Demogorgon's exuberant addresses to the Earth, the moon, and the "happy dead" (IV.524ff.) must seem curiously hollow when placed, in a kind of collage, opposite

29The Role of the Reader: Explorations in the Semiotics of Texts (Bloomington: Indiana University Press, 1984), p. 49 .

30Ibid.

${ }^{31}$ Twilight of the Idols, in Twilight of the Idols and The Anti-Christ, trans. R. J. Hollingdale (Harmondsworth: Penguin, 1968), p. $3^{8}$. 
the Magus Zoroaster's encounter with his own shadow and the subsequent disclosure that Demogorgon, too, is no more than a shadow. Similarly, the song of the Spirits, with its movement beyond the veil of life and death, is set against the equivocal conversation between Asia and Demogorgon, and displaced into the vacant pages used for corrections and afterthoughts. It thus loses its lyrical immediacy and becomes an echo of itself, the object of a Brechtian alienation effect. Again and again, it is as though the play is quoting itself and reducing mimesis and voice to text. But the odd juxtapositions do not necessarily work toward dismantling the Promethean drama. The conjunction of the last and first act, like one of those windows into eternity of which Blake speaks, can also be seen as opening up a vista that act I by itself denies us, thus reducing act I to quotation. It is as if copying out the text without preparing it for print freed Shelley to compose and decompose it, so as to dissolve in his mind any illusion that the form he finally gave it was inevitable.

It is appropriate to conclude with some theoretical reflections. The idea of the text as performance, while it accommodates a hermeneutic reading, is philosophically very different from the reading dramatized in the dialogue between Asia and Panthea, which assumes that we can grasp the identity of the text. But as I have already suggested, traditional hermeneutics contains the traces that lead to its own deconstruction, as to some extent does poststructuralism. Both contain tendencies to reify interpretation that are at odds with their insistence that we intertextualize fiction and reality. Hermeneutics, as we have seen, requires that literature enter the world of communication in order to be brought to life, yet clings to a dualism of work and text that makes the work an essence unchanged by its existence in the communicative process. Poststructuralism, on the other hand, de-idealizes the notion of literature as a special form of language, protected by a dualism that privileges it above other forms of discourse. But it of ten ends by underprivileging literary discourse, thus reverting to a dualism that denies language the power to affect reality. I have suggested here that what Prometheus $U n$ bound responds to is an approach that intertextualizes fiction and 'reality,' and recognizes that they mutually make and remake each other. But the attempt to construct this approach from interpretive interludes in the play and from the theory of the romantic period itself marks a reluctance to engage in the ahistorical and paradigmatic reading that Frank Lentricchia criticized in Yale deconstruction: ${ }^{32}$ reading that assumes that the interpretation of a particular text is a paradigm for the interpretation of all other texts. Prometheus Unbound is a particular kind 
of text, and a strictly poststructuralist approach may well be appropriate for a different kind of text such as the French nouveau roman. As a play that has elements of political allegory, it belongs with works like Blake's Songs and prophecies, the reformist novels of Godwin and Wollstonecraft, even Wordsworth's Prelude: in other words, with works that assume the interaction of fiction and sociopolitical reality, fiction and personal life. But as a text that claims some relationship between literature and history, it also recognizes its own vulnerability to having its significance constituted differently by different readers. For the semiotics of theater is not identical with the semiotics of the book, the former being a performance that is subject to change. In choosing the mode of drama, Shelley departs from Alastor to set his work in the space of historical difference and forfeits for it the closure of a classic that can codify its message. To adapt a phrase from "Mont Blanc," the text "governs thought" but does not originate it: it remains a presence in the world, but no longer one that can institutionalize meaning. 